shun the unfortunate sufferers from consumption, provided they are cleanly in their habits.

If we all have tuberculosis, the futility of directing our prophylactic measure chiefly against the bacilli, as has been so commonly done in recent years, becomes at once apparent, and we must realize that such measures are only a small part in the battle against the white plague, and that they are of far less importance than securing highly resistant bodies by good heredity, good environment and sane living.

$$
\text { E. Fletcher Ingals, Chicago. }
$$

\section{The Responsibility of the Mentally Subnormal}

To the Editor:-Your editorial on the above subject (Oct. 23, 1909, liii, 1403) is sound. No man who has committed a murder and who has been judged irresponsible may safely be entrusted with liberty. With the knowledge that his past record of insanity renders him immune to punishment, be has little to deter him from a repetition of his antisocial act; and an act once successfully committed is, under such circumstances, a constant invitation to its repetition.

Whether the state should feel obliged to support at its expense those who are a constant menace to others and who cannot possibly be useful citizens, I cannot say; there might be a more summary way of dealing with them; but if there be no death penalty certainly there should be no less than a life sentence for them.

The man with a mental make-up which sets at naught the right of his neighbor to die a natural death certainly has no right to be at liberty, whether he is what is ordinarily called "responsible" or not. The very fact that he is of that nake-up renders him irresponsible and it is the state's duty, the first time this becomes apparent, to take care of him.

$$
\text { G. H. HEALD, Washington, D. C. }
$$

\section{The Netting Eye-Shield}

To the Editor:-The improved eye-bandage described and illustrated by Dr. C. W. Talbot (The JournaL, Oct. 30, 1909, liii, 1487) is exactly like the Fuchs Schutzgitter (latticeshield) which has been in use in the clinic in Vienna for the past twenty-five years. It is described in Elschnig's edition of Czermak and also in all text-books on ophthalmic surgery.

It seems that an author should examine into the originality of his device before publishing a claim for originality, and that The Jotrical is also at fault for inserting the description in its worthy columns.

Jesse S. WyLER, Cincinnati.

\section{Association News}

\section{Trustees' Meeting}

The Trustees of the American Medical Association met in Chicago October 22 and 23, at the rooms of the Association. Three sessions were held on Friday, October 22, and one on Saturday, October 23. There were present at all sessions:

Dr. M. L. Harris, Chicago (Chairman).

Dr. Wisner R. Townsend, New York (Secretary).

Dr. Philip Marvel, Atlantic City, N. J. (Vice-chairman).

Dr. W. W. Grant, Denver, Colo.

Dr. Philip Mills Jones, San Francisco, Cal.

Dr. W. T. Councilman, Boston, Mass.

Dr. W. T. Sarles, Sparta, Wis.

Dr. C. E. Cantrell, Greenville, Texas.

Dr. C. A. Daugherty, South Bend, Ind.

The first session on Friday was held from 10 a. m. to 12:30 p. m. The secretary reported that since the last meeting the following circular letter had been sent the chairmen of all standing and special committees, and that replies had been received from all:

"On September 10 the following notice was sent to you:
Your attention is respectfully called to the following resolutions which are in effect in the Board of Trustees:

First: That all annual appropriations be made to date from the termination of the annual session to the termination of the next annual session.

Second: That appropriations so made must not be exceeded.

Third: That suitable blanks for use by committees, etc., in making applications, bills, etc., will be provided on application to the Secretary of the Association, Dr. George H. Simmons, 535 Dearborn Avenue, Chicago, III.

The Trustees would kindly request that you present an estimate of the funds needed for the ensuing year to the Secretary on or before October 1 as there will be a full meeting of the Board in october, wher the matter will be taken into consideration.

Your attention is respectfully called to the following amendments to the By-Laws which were passed by the House of Delegates at Altantic City :

Chapter IX, Section 1: Add to the section the words "during the intervals between the sessions of the House of Delegates, the Board of Trustees shall supervise the action of committees constituted by action of the urouse."

chapter $x$, Section 1: Add to the section the words "any of these committees, acting during the intervals between the sessions of the House of Delegates shall be subject to the Board of Trustees."

"Should your committee desire to take any action during the intervals between the meetings of the House that would be governed by either of the above sections, won't you kindly first communicate with the Chairman of the Board of Trustees, Dr. M. L. Harris, 100 State street, Chicago, Ill., in order that the matter may be officially brought to the Board's attention.

$$
\text { "Yours very truly, }
$$

"M. L. Harris, Chairman,

"Wisner R. Townsend, Secretary."

Dr. Harris, as Chairman of the Committee on Arrangements for the next meeting, reported that he had visited St. Louis and had arranged for Dr. Dorsett to act as Chairman of the Local Committee on Arrangements.

Dr. Harris, Chairman of the Committee on Postal Relations of THE Jounval, reported progress, and stated that the action of the Board of Trustees and House of Delegates at Atlantic City, had been duly forwarded to the Third Assistant Postmaster General, and receipt acknowledged.

A letter from Dr. Wynn, outlining a plan for providing an exhibit of an educational nature, was read and Dr. Wynn was requested to present more definite data at the next meeting of the Board.

A letter from Dr. Reed was read, asking for an interpretation of the amendments to the by-laws made at Atlantic City. After a discussion of the same the following resolution was passed:

In accordance with the Amendments of By-Laws passed at the last meeting, at Atlantic City, wbich Amendments were passed without the knowledge or solicitation of this Board, it feels that it is the duty of the Board of Trustees to supervise the work of all comduty of

The Board discussed fully the question of THE Journal advertising and approved of the work and methods in use in that department.

SECOND SESSION, HELD FROM $3: 15$ TO 6:30 P. M.

A letter was read from the Honorable Seth Low, of the National Civic Federation, asking that delegates be appointed for the meeting to be held in Washington, Jan. 5, 1910, next, by that body. The Board passed a resolution requesting the president, Dr. Gorgas, to appoint six delegates to represent the American Medical Association.

The subject of the publication, by the Association, of books, was discussed and a committee appointed to consider the subject more fully.

Letters from the various committees asking for appropriations for the year were then taken up, and each matter con. sidered separately. After full discussion on the needs of the committees, so far as the Board could ascertain, the following appropriations were made for the year 1909, these appropriations to apply from the termination of one annual meeting to the termination of the next annual meeting:

\section{BUDGET FOR 1909-1910}

Amount Appropriated.

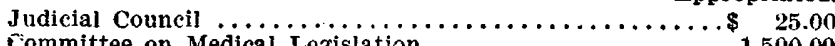
Committee on Medical Legislation. ............ Committee on Transportation and Place of Session...... 25.00 